\title{
11. Heidegger's Allegory of Reading: On Nietzsche and the Tradition
}

William D. Melaney, Cairo, Egypt

Heidegger's interpretation of Nietzsche has been canonized in the philosophical tradition as an almost perfect demonstration of how the forgetfulness of Being continues the dominant positions of modern metaphysics. A close examination of available sources often corroborates the canonical view, which enables us to appreciate the general coherence of Heidegger's philosophy and to assess his merits as a Nietzsche critic. However, the role of reading in the interpretative process casts a different light on Heidegger's approach to Nietzsche and his relationship to the philosophical tradition. Particularly as employed in the late work of Paul de Man, reading is a technical term that refers to our mode of access to texts, but also to the capacity of criticism to open up non-totalizing interpretations of traditional works. ${ }^{1}$ This paper is concerned with three aspects of Heidegger's work, namely, (i) the role of Kant and Schopenhauer in Nietzsche's critique of metaphysics; (ii) Nietzsche's "inversion" of Platonism; and (iii) Heidegger's contribution to a hermeneutical reappraisal of Nietzsche's thought. The importance of reading to all three aspects of Heidegger's approach to Nietzsche will perform a pivotal role in this discussion.

It may seem ironic that Heidegger should begin rather early in his lectures on Nietzsche with a defense of Kant's aesthetic theory, rather than with a recapitulation of the ontological criticism that he developed in previous contexts. In a famous public debate with Ernst Cassi-

1 Paul de Man, Allegories of Reading. Figural Language in Rousseau, Nietzsche, Rilke and Proust, New Haven and London 1979. 
rer, Heidegger repeatedly emphasized the role of intuition and the imagination to a proper understanding of Kant's philosophy. ${ }^{2}$ In opposition to the established tendency to interpret Kant either in narrowly scientific terms, or as a kind of modern Plato, Heidegger undertakes the difficult task of reassessing the "metaphysical" significance of the transcendental problematic. For Heidegger, however, metaphysics itself acquires an entirely new meaning through multiple interpretations of philosophical and literary works during the period of Sein und Zeit and extending into the years following its publication. Instead of functioning in the traditional manner as a term that describes the attempt to privilege the intelligible over the sensible world, metaphysics is redefined as the properly ontological concern of Dasein.

While the issue of art does not emerge strongly in the CassirerHeidegger debate, we can easily envision how the basic concerns of aesthetic experience might have figured in a more complete version of this encounter. In Heidegger's interpretation of Nietzsche, we soon discover that the doctrine of beauty as enunciated in Kant's aesthetics ${ }^{3}$ is assigned a positive significance that has little to do with either its neo-Kantian appropriation or with the metaphysical misinterpretation that Nietzsche assigned to it. Heidegger clearly attributes Nietzsche's misinterpretation of Kant to the lingering influence of Schopenhauer, whose conception of the will no doubt stood in the way of a basically "classical" view of the beautiful. ${ }^{4}$ From Heidegger's standpoint, Nietzsche misinterprets Kant's definition of the beautiful as "devoid of all interest" in two ways: first, this phrase is taken out of context and misunderstood as the sole criterion for judging the beautiful; second, it

2 Martin Heidegger, Kant and the Problem of Metaphysics, trans. by Richard Taft, Bloomington 1997.

3 Immanuel Kant, Critique of Judgment, trans. by J. H. Bernard, Amherst 2000 .

4 See also Maudemarie Clark, Nietzsche on Truth and Philosophy, Cambridge and New York 1990. 
is falsely assumed to exclude all other relations to the aesthetic object. Heidegger argues, on the contrary, that Kant's criterion of disinterestedness actually frees the object to appear in a pure way. Rather than interpret disinterestedness as simply a limiting condition, Heidegger assimilates it to a mode of being that enables the object to appear as such: The word "beautiful" means appearing in the radiance of such coming to the fore. ${ }^{5}$

It would have been impossible for Heidegger's early readers to miss the phenomenological resonance of this description of the beautiful. Granted, his re-interpretation of "disinterestedness" may overlook the scientific character of Kant's aesthetic project, which harbors the modern bias in favor of subjectivity as a guiding principle. Heidegger's description of the beautiful does not allow us to assimilate Kant's achievement to the sweeping (and perhaps totalizing) characterization of modernity that assigns subjectivity a predominantly negative significance. Thus, while the hermeneutics of Gadamer ${ }^{6}$ represents a modified version of this interpretation, we are somewhat surprised to discover that Heidegger's defense of Kant against Nietzsche also contains a "hermeneutical" core insofar as it reemphasizes the role of interpretation in the apprehension of an aesthetic appearance which enables the "things themselves" to emerge in all their radiant beauty.

At the same time, Heidegger does not merely criticize Nietzsche as an interpreter of Kant but readily admits that matters of philosophical originality are sometimes quite distinct from matters of scholarship. Perhaps Nietzsche's misreading of Kant can be distinguished from the false interpretation that he adopts from Schopenhauer. As a hermeneutical concept, the misreading of a text can constitute the basis for a

5 Martin Heidegger, "The Will to Power as Art", trans. by David F. Krell; in: Nietzsche i, New York 1979, 110.

6 Hans-Georg Gadamer, Truth and Method, trans. by Joel Weinsheimer and Donald G. Marshall, New York 1991. 
productive reading that opens up a new line of interpretation. Heidegger recognizes that Nietzsche's genealogical approach to intellectual history is almost necessarily overdetermined insofar as it affirms the importance of physical life over traditional assumptions concerning the origin of ideas. From the genealogical standpoint, both Kant and Schopenhauer follow Platonic directives ${ }^{7}$ in elevating noumenal over phenomenal relations on the basis of an underlying ontological difference. From this standpoint, we might consider that Nietzsche's misreading of Kant is what allows him to assert the importance of appearances over the metaphysical denial of an apparent world.

Heidegger locates Nietzsche's response to Kant's aesthetics in a critical genealogy that identifies rapture as "form-engendering force" in a revised notion of aesthetic experience. The significance of rapture cannot be grasped unless Kantian and post-Kantian conceptions of the aesthetic are held in view: "Rapture as a state of being explodes the very subjectivity of the subject." In turning from Kant, Nietzsche discovers an alternative to metaphysics as the apotheosis of non-sensuous beings and begins to assign physical life a new meaning in a narrative that cannot be read in a purely idealistic manner. The death of the subject that his philosophy announces can be related to the attempt to retrieve a realm of being that has been denigrated since the origin of metaphysics. In calling attention to this movement away from the whole concept of the subject, Heidegger is able to suggest how Nietzsche came to perform a crucial role in contemporary thought.

And yet, while approaching the problem of aesthetics in an original manner, Nietzsche also risks transferring the dangers of subjectivity into the work of art itself. Heidegger suggests that, as a postWagnerian, Nietzsche often fails to recognize the importance of the

Plato, The Republic of Plato, trans. by Allan Bloom, New York 1991. Heidegger, "The Will to Power as Art"; in: Nietzsche i, 123. 
artistic work as a relatively stable entity that can be approached apart from the subjectivity of the artist. Heidegger's remarkable essay, "Der Ursprung des Kunstwerkes," appears in its earliest versions as a series of lectures that were given at Freiburg and Zürich in 1935-36. ${ }^{9}$ Heidegger's early lectures on Nietzsche were also presented during this same period and also reflect an interest in calling attention to the work-character of art, which functions to limit the subjectivism inherent in modern aesthetics. Gadamer, of course, develops this aspect of Heidegger's philosophy in his criticisms of Kantian aesthetics and in his attempt to recover the ontological meaning of the work of art. During this phase of his research, however, Heidegger merely remarks that "through the presentation of Nietzsche's aesthetics offered here it ought to have become clear by now how little he treats the work of art." 10

Thus, Heidegger basically reads Nietzsche's approach to art through a thematic of instability that challenges received interpretations of the philosophical tradition. For example, in acknowledging that Nietzsche was always interested in clarifying the relationship between art and truth, Heidegger also contends that his concept of truth was never developed beyond the positions of Plato and Aristotle, which were later enshrined uncritically in the exemplars of early modern thought. From this standpoint, Nietzsche does not represent a significant advance over the epistemology of Descartes. Hence, while defining truth in terms of error, he refers his definition to a notion of certitude that lies at the heart of the Cartesian theory of knowledge. Nietzsche's divergence from the Cartesian tradition is therefore somewhat deceptive, since the view that truth is related to the role of error in the struggle for knowledge can be linked to a thematic of cer-

9 Martin Heidegger, "The Origin of the Work of Art"; in: Poetry Language Thought, trans. by Albert Hofstadter, New York 1971, 15-87.

10 Heidegger, "The Will to Power as Art"; in: Nietzsche i, 118. 
titude that constitutes the model for interpreting the world in the first place.

Moreover, Heidegger establishes the thematic of instability on a deeper level in identifying the "fundamental experience" that enabled Nietzsche to confront the problem of metaphysics in a new way. This experience is that of nihilism, which constitutes the gravest threat to the survival of metaphysics in its "classical" form. In Heidegger's account, this experience of nihilism is inseparable from the death of God, just as it constitutes an event (Ereignis) of overwhelming historical importance: "The phrase 'God is dead' is not an atheistic proclamation: it is a formula for the fundamental experience of an event in Occidental history."11 In genealogical terms, Nietzsche's pronouncement implicates Christianity in the history of nihilism, which begins as metaphysics. The connection between Christianity and Platonism has been clearly established in numerous studies, but Nietzsche invites us to rethink this relationship, not on the level of historical influence, but in terms of shared patterns of denial that demonstrate mutual complicity.

Nietzsche's interpretation of Plato becomes crucial, therefore, within the context of historical genealogy, the new science that ultimately enables him to interpret cultural phenomena in semiotic ways. On the basis of Nietzsche's criticism of traditional metaphysics, we might easily assume that he was unambiguous in his rejection of both Plato and Platonism. It is true that Nietzsche distinguishes Plato from Platonism largely due to issues of historical influence as opposed to authorial meaning. From this standpoint, Heidegger is sometimes assumed to have argued that Nietzsche's philosophy constitutes an "inversion of Platonism" that simply reverses what the classical philosopher asserted to be true. However, Heidegger cannot be identified with this uncomplicated reading. If this were Heidegger's reading,

11 Heidegger, "The Will to Power as Art"; in: Nietzsche i, 156. 
then he would not need to argue that Nietzsche conceived of the relationship between art and truth as one of discordance. And yet, Heidegger reminds us that Nietzsche's challenge to traditional metaphysics seriously destabilizes this thought: "He speaks of the discordance that arouses dread, not in the period prior to his overturning Platonism, but precisely during the period in which the inversion is decided for him."12

Furthermore, Heidegger discovers signs of this discordance in the deep structure of Platonic metaphysics. In his analysis of Plato's Republic, Heidegger identifies the eidos that inspires the craftsman with an outward appearance of the thing to be produced, rather than with an abstract "concept" that allegedly underlies the phenomenon. At the same time, the eidos in no way depends on what the craftsman makes but is what enables him to "frame" his work according to what is proscribed. Hence the craftsman allows things to become present as phenomena, that is, as appearances that in some way correspond to ideas. However, the nature of this correspondence remains difficult to determine. Since the craftsman does not produce the eidos, he is essentially estranged from the being of the thing produced. From this perspective, the material thing can only detract from the original radiance of this idea. Heidegger attempts to explain why it is hard to translate the term that aptly describes this process: "The Greek word amydron is difficult to translate: for one thing it means the darkening and distorting of what comes to presence." ${ }^{, 13}$ According to the implicit analogy between art and craftsmanship, the element of "darkening and distorting" inherent in all production establishes an irrevocable distance between art and truth.

This does not mean, however, that Heidegger interprets Plato as providing the model for a basic discordance that Nietzsche simply ap-

12 Heidegger, "The Will to Power as Art"; in: Nietzsche i, 162-63.

13 Heidegger, "The Will to Power as Art"; in: Nietzsche i, 180. 
propriates in a new key. On the contrary, Plato's doctrine of beauty provides a crucial example of "felicitous discordance," that is, temporary estrangement followed by the harmonious attainment of truth. Hence beauty and truth are distinguished but related as differently attuned to an experience of radiance that posits Being in nondiscordance. Heidegger interprets Nietzsche's dreadful sense of discordance in relation to a resolution of discord that occurs in Plato and traditional Platonism. It is evident to Heidegger that Nietzsche interprets Plato as functioning in terms of a clearly articulated form of metaphysical dualism. For this reason, Nietzsche cannot simply challenge traditional Platonism in a manner that leaves everything intact after basic structures have been displaced and perhaps dismantled.

Hence, when referring to Nietzsche's attempt to "overturn" Platonism, Heidegger does not contend that the process of overturning involves the simple negation, let alone destruction, of an earlier position. The confrontation with the "true world" does not install the "apparent world" in its place. On the contrary, the apparent world also collapses when the true world ceases to be: "Only then is Platonism overcome, which is to say, inverted in such a way that philosophical thinking twists free of it." The metaphor of "twisting free" is particularly revealing in that it communicates both the act of breaking away and the incomplete nature of liberation. The two-fold significance of this expression prevents us from interpreting Nietzsche's refutation of Plato as either Enlightenment-style critique or as the perpetuation of the philosophical tradition in some new guise.

Heidegger argues that Nietzsche does not arrive at a full understanding of his mature position until very late in his career. In Götzendämmerung, composed in 1888, Nietzsche presents a dense outline of how metaphysics came to an end through a narrative entitled, "How the 'True World' Finally Became a Fable: The History of 
an Error." ${ }^{14}$ In this genealogical tale, Nietzsche produces an allegory of reading that specifies how Platonism is affirmed as true, appropriated as Christianity, reduced to the status of ethics and finally denied in the style of scientific positivism, before it yields to the message of Zarathustra. Heidegger discusses this final, Nietzschean phase in terms of two related moments. During the first moment, the "true world" is abolished, but "the vacant niche of the higher world remains, and so does the blueprint of an 'above and below,' which is to say, so does Platonism. ${ }^{, 15}$ For Heidegger, this first phase is best represented by Nietzsche's so-called middle period. However, Heidegger also maintains that Nietzsche moves beyond this "positivist" period in abolishing the apparent world as well. It is not possible to simply do away with the "true world" in a dualistic cosmology. Heidegger's conclusion is consistent with the tenor of his analysis: "A new hierarchy and new valuation mean that the ordering structure must be changed." 16

Heidegger relates the abolition of the true and apparent worlds to the emergence of an abyss that renews the meaning of metaphysics in Nietzsche's later work. This abyss is that of life, which is recognized as a contradictory phenomenon that integrates various perspectives in order to function as a coherent entity. The perspectives that enable life to flourish coordinate an encounter with appearances, which constitute the core of reality itself. "Semblance" is now assigned metaphysical significance to the degree that Nietzsche maintains "that being-real is in itself perspectival, a bringing forth into appearances, a letting radiate; that it is in itself a shining. Reality is radiance." ${ }^{, 17}$ Heidegger

14 Friedrich Nietzsche, Götzen-Dämmerung; in: Kritische Studienausgabe (= KSA), ed. by Georgio Colli and Marrino Montinari, Berlin and New York 1980, Vol. 6, 55-161.

15 Heidegger, "The Will to Power as Art"; in: Nietzsche i, 207.

16 Heidegger, "The Will to Power as Art"; in: Nietzsche i, 209.

17 Heidegger, "The Will to Power as Art"; in: Nietzsche i, 215. 
therefore makes definite claims about Nietzsche's status as a metaphysician. Nietzsche is said to espouse a belief in life that "overturns" traditional metaphysics. Nonetheless, Heidegger continues to refer to Nietzsche as a metaphysician who reinterprets the question of being in terms of a revised notion of appearances.

Is Heidegger justified in describing Nietzsche as a metaphysician? Nietzsche turns the history of metaphysics into an allegory, and then Heidegger reads Nietzsche as opposing the traditional idea that reality is stable and unchanging. Heidegger therefore provides an allegory of reading in reading Nietzsche as an allegorist who overturns the metaphysical assumptions that generally govern our interpretation of reality. However, the category of the real is not thereby refuted but assigned a new meaning in a situation where even art comes to be interpreted as a language that "expresses" a reality that assumes the significance of will to power in an open economy of limitless transformations. Reality, when interpreted as will to power, assumes the status of a ground that ultimately exceeds the totality of perspectives that are applied to it. On the other hand, in arguing in favor of Nietzsche's renewal of metaphysics, Heidegger seems to place him in the paradoxically Kantian position of separating reality (as an extralinguistic and unknowable thing-in-itself) from the perspectives that enable us to experience the real as the product of human mediation. How can this inconsistent interpretation be acceptable?

The way out of this apparent impasse has been perhaps most skillfully explored by Eric Blondel, whose work on Nietzsche has the hermeneutical value of deepening our reading of Heidegger. ${ }^{18}$ Blondel clearly indicates that Nietzsche both evokes the reality of a quasiphysical "text" that functions negatively with regards to metaphysical illusions and also marshals various "interpretations" (as drawn from

18 Eric Blondel, Nietzsche: The Body and Culture; Philosophy as a Philological Genealogy, trans. by Seán Hand, Stanford 1991. 
various discourses of the human sciences) in order to detract from the objective character of his approach to the world. Hence the apparent rapprochement with Kant is actually quite different, since the distinction between text and interpretation prevents metaphysics from reemerging as either the apotheosis of a physical "it-itself" or as the substitution of interpretation for reality. This scheme, if properly understood, should prevent us from turning the will to power into the text that underlies every interpretation.

Heidegger's work on Nietzsche continues to be important as a philosophical inquiry and scholarly resource. His reading is often capable of alerting us to the dangers of totalization that are inherent in Nietzsche's own thinking. In confronting the strengths and weaknesses of his subject, he encourages us to place Nietzsche in an intellectual context that is appropriate to a major figure in the modern tradition. However, in overextending the metaphysical significance of Nietzsche's philosophy, he ultimately risks collapsing the difference between text and interpretation upon which his own reading depends. It is in the hope that Heidegger's allegory of reading can be appreciated as a non-totalizing discourse that we return to his seminal contribution to the difficult task of interpreting Nietzsche. 